\title{
Alternatives to Sowing Vegetable type Soybeans
}

\author{
Edcarlos Mannfredini ${ }^{1}$, Deonisio Destro ${ }^{*^{2}}$, Martin Homechin $^{2}$, Gustavo Sachsida ${ }^{3}$ and Édison \\ Miglioranza ${ }^{2}$ \\ ${ }^{1}$ Bolsista CNPq, Engenheiro Agronômo pela Universidade Estadual de Londrina (UEL), Caixa Postal 6.001, CEP \\ 86051-990 Londrina, PR. ${ }^{2}$ Engenheiro Agronômo, Doutor, Prof. Associado, do Departamento de Agronomia da \\ UEL, Caixa Postal 6.001, CEP 86051-990 Londrina, PR. ${ }^{3}$ Graduando em Engenharia Agronômica do \\ Departamento de Agronomia da UEL, Caixa Postal 6.001, CEP 86051-990 Londrina, PR, Bolsista pelo CNPq- \\ PIBIC.
}

\begin{abstract}
Today, soybean crops of the Tamba Kurodaisu cultivar are sown in beds prior to transplantation to the field. This planting system has caused crop failure due to damage to the root system. An experiment to test different sowing alternatives to obtain plantlets for cropping of food type big seeded soybean was set up with the following treatments: sowing in beds; sowing in $130 \mathrm{~cm}^{3}$ newspaper cups; sowing in test tubes of volumes of $30 \mathrm{~cm}^{3}, 60 \mathrm{~cm}^{3}$ and $70 \mathrm{~cm}^{3}$; sowing in $70 \mathrm{~cm}^{3}$ disposable plastic cups; sowing on $90 \mathrm{~cm}^{3}$ styrofoam trays. A randomized complete block design was used, and the following traits were assessed: germination percentage; number of days to flowering; plant height at flowering; number of days to maturity; plant height at maturity; number of seeds per plant; individual plant yield; weight of a hundred seeds. Results should that three methods could be used to set up Tamba Kurodaisu cultivar crops: sowing in disposable plastic cups, sowing in beds with later transplant, or direct sowing in the field.
\end{abstract}

Key words: food type soybean, vegetable soybean, edamame.

\section{INTRODUCTION}

Chemical analysis of soybean (Glycine $\max$ (L.) Merrill) shows it to be an excellent source of proteins and calories and classify it as one of the five protein supplying foods (meat, milk, eggs, cheese and soybean). Soybean can be helpful in improving the nutrition of the Brazilian people because it offers several advantages such as: a) it can be cultivated in nearly the whole country; b) it has a greater protein and calorie content than other vegetable species cultivated in Brazil; c) low cost per protein unit; d) many culinary uses; e) soybean has been used for centuries in the Far East, and its human consumption is growing in a geometric progression in the industrialized countries (Carrão-Panizzi, 1988).

Some organoleptic characteristics have caused limitations in soybean acceptance. However, these problems can be overcome in the industrial process or with correct domestic preparation. The use of soybean in natura should be considered, mainly when a economical product is required.

According to Vello (1992), food type soybean can be classified by seed size which is assessed by the weight of a hundred seeds (WHS). Grain type soybean has medium sized seeds with WHS varying from 10 to $19 \mathrm{~g} / 100$ seeds. Except for sprouts and "natto" (fermented soybean) which use small seeds ( $<$ than $10 \mathrm{~g} / 100$ seeds), food type soybean usually has large seeds $(>20 \mathrm{~g} / 100$ seeds). Soybean with large seeds is called "vegetable soybean" in the United States and "edamame" in Japan.

Genotypes with special characteristics are considered food type soybean. They have a

*Author for correspondence 
sweetish nutlike flavour, higher and better quality protein content, lower oil content, better quality oil and cook quickly (Destro, 1991).

The large seed size has some advantages such as: a) lower hypocotil/cotyledon proportion, which improves the flavor; b) easier removal of the seed coat, which is required in some industrial food processes (Vello, 1992); c) rapid cooking; and d) milder flavor compared with the cultivars used for the oil and meal industry (Hartwig, 1973).

Food type soybean cultivars may be used to prepare tofu (cheese), tempeh (fried dough), miso (soup), tonnyu (extracted liquid like milk), shoyu (sauce), and to make a sweet, traditionally eaten to commemorate the New Year in Japan. It is also used as an aperitif: the green pods are lightly cooked in salted water and the grains are extracted and eaten with the fingers. As a vegetable, the grains may be mixed in salads, stir fried or combined with other vegetables. Occasionally, confectionery products are made, such as rice pudding with soybean topping (Konovsky, 1990). "Edamame" soybean pods are sold fresh, on the stem, with leaves and roots or without the leaves, as immature beans $\left(\mathrm{R}_{6}\right.$ stage of the scale of Fehr \& Caviness, 1977). They may even be taken off the stem and packed fresh or frozen, either as pod or grains (Konovsky, 1990).

The use of soybean as a food is a centuries-old tradition in oriental countries, especially Japan, China and Taiwan. It is also used in countries such as Thailand, Nepal, the Philippines, Indonesia, Sri-Lanka, Malaysia, Singapore, the United States and Australia. In some countries such as Thailand and Nepal, soybean cultivars used for industry are also used as if they were food-type soybean. Research with "edamame" soybean is limited when compared to that on soybean for industry. Several seed companies in Japan carry out research to develop soybean cultivars for human nutrition. Taiwan has approximately 10,000 ha cultivated with this type of soybean and the majority of the production is exported to Japan (Shanmugasundaram, 1990).
The cultivated area with food type soybean in Japan has increased in recent years, but the total production and the average yield per hectare has decreased during the same period. The total Japanese consumption of this soybean is approximately 150,000 tons of green pods per year. Japan imports approximately 30,000 to 50,000 tons of frozen "edamame" soybean, mainly from Taiwan. There was insignificant production in Taiwan in 1975, but the cropped area increased to more than 10,000 hectares by 1989. The average pod yield varied from 5.0 to 6.4 tons per hectare. Taiwan domestic consumption increased from 4,500 tons in 1984 to 14,000 tons in 1989 (Shanmugasundaram, 1990).

Lines of food type soybean were developed in Asia (approximately $40^{\circ}$ latitude) and have short juvenile period. These genotypes when cropped under short day conditions, in Brazil, flower early and show a reduced number of nodes, plant height and consequently yield. Santos (1988) and Destro et al. (1994) observed that soybean introduced from Japan had the disadvantage of a low physiological seed quality which reduced the germination and emergence capacity of the seedling in the field.

Tamba Kurodaisu soybean is presently sown in beds and approximately 5 days after emergence, the seedlings are transplanted to the field. This system has caused problems in the field due to root system damage and pathogens attack reducing the yield.

This study was carried out to test different sowing alternatives for soybean plantlets with the intent of establishing good soybean crops with the Tamba Kurodaisu cultivar (weight of a hundred seeds more than $20 \mathrm{~g}$ ).

\section{MATERIALS AND METHODS}

The experiment was carried out on the School Farm at the State University of Londrina, located at $23^{\circ} 22^{\prime} \mathrm{S}$ latitude, $51^{\circ} 10^{\prime} \mathrm{W}$ longitude and altitude of 585 meters in Latossolo Roxo. The seeds were sown on November 17, 1996 and harvested during March 
and April 1997. The experimental material was the Tamba Kurodaisu soybean cultivar, which has a black seed coat (intense antocianine) and big seed size (weight of a hundred seeds more than 20 g) (Destro, 1991). A randomized complete block design with 7 treatments and 4 replications was used. The treatments tested were:

1. Sowing in flower beds, with later transplant to the field;

2. Sowing in newspaper cups, made from rolled newspaper pages, with two layers of paper, as in tomato cultivation, $\mathrm{V}=130$ $\mathrm{cm}^{3},(\varnothing=4.7 \mathrm{~cm}$ and $\mathrm{H}=7.5 \mathrm{~cm})$;

3. sowing in test tubes, $\mathrm{V}=30 \mathrm{~cm}^{3},(\varnothing=$ $2.6 \mathrm{~cm}$ and $\mathrm{H}=7.2 \mathrm{~cm}$ );

4. Sowing in test tubes, $\mathrm{V}=60 \mathrm{~cm}^{3},(\varnothing=$ $2.6 \mathrm{~cm}$ and $\mathrm{H}=12.1 \mathrm{~cm}$ );

5. Sowing in test tubes, $\mathrm{V}=70 \mathrm{~cm}^{3},(\varnothing=$ $2.6 \mathrm{~cm}$ and $\mathrm{H}=14.7 \mathrm{~cm}$ );

6. Sowing in disposable plastic cups, $\mathrm{V}=70$ $\mathrm{cm}^{3},(\varnothing=6.0 \mathrm{~cm}$ and $\mathrm{H}=7.5 \mathrm{~cm})$;

7. Sowing in extruded polystyrene trays, $\mathrm{V}=90 \mathrm{~cm}^{3},(\varnothing=4.0 \mathrm{~cm}$ and $\mathrm{H}=8.0 \mathrm{~cm})$; where:

V: Container volume;

$\varnothing$ : Diameter of container base and top; and $\mathrm{H}$ : Container height.

The containers were filled with substrates based on humus (40\%), Latossolo Roxo subsoil (40\%) and vermiculite $(20 \%)$. Four hundred seeds per treatment were sown manually, and transplanted to the field 12 days after emergence $\left(\mathrm{V}_{\mathrm{c}}\right.$ and $\mathrm{V}_{1}$ Stages of the scale of Fehr \& Caviness, 1977). Each plot consisted of a $9.6 \mathrm{~m}$ row, with 24 plants spaced at $0.4 \mathrm{~m}$. Row (plot) spacing was $0.6 \mathrm{~m}$. Following the technical recommendations from Embrapa Soja (1996), and the soil analysis, $20 \mathrm{~g} / \mathrm{meter}$ of formulated fertilizer (00-20-20) were applied at a depth of $15 \mathrm{~cm}$. Weeds control was done manually. Spraying of endosulphan based insecticide was carried out to control stink bugs. The plants were pulled up by hand at harvest, identified for later manual threshing and individual weighing. The following characteristics were assessed:
GP : Germination percentage;

NPP: Number of plants per plot, at 7, 14 and 21 days after transplant, at flowering and maturity.

NDF: Number of days to flowering. This was the period between sowing and the opening of the first flower $\left(\mathrm{R}_{1}\right.$ stage of the scale of Fehr \& Caviness, 1977).

PHF: Plant height $(\mathrm{cm})$ at flowering. Average distance between the soil and the insertion of the highest inflorescence on the main stem;

NDM: Number of days to maturity. The period between sowing and the day when approximately $95 \%$ of the pods were ripe.

PHM: Plant height $(\mathrm{cm})$ at maturity. Average distance between the soil and the insertion of the highest pod on the main stem;

NSP: Number of seeds per plant;

IPP: Individual plant productivity. Assessed after threshing, by weighing the grains from the individual plants;

WHS: Weight of a hundred seeds, obtained by the following formula:

$$
\mathrm{WHS}=\frac{\mathrm{IPP}}{\mathrm{NSP}} 100
$$

where: WHS: weight of a hundred seeds;

IPP: productivity per individual plant; NSP: number of seeds per plant.

The plot mean for all the characters assessed, which corresponded to the replication mean, was calculated based on observation of all the plants of the plot. Each treatment mean was calculated by the mean of the four plots. The $\mathrm{F}$ test was used in the analysis of variance to assess the significance of the differences among the treatment means. The Duncan test was used for the mean comparisons.

\section{RESULTS AND DISCUSSION}

Each treatment mean for the agronomic traits, general mean, variation coefficients $(\mathrm{VC})$ and $\mathrm{F}$ value are presented in Table 1. Except for the 
number of seeds per plant and yield per individual plant, all traits had low variation coefficients (VC), varying from $1.06 \%$ for the number of days to flowering to $9.12 \%$ for the plant height at flowering. The VC were $27.6 \%$ for the number of seeds per plant and $29.8 \%$ for individual plant productivity, indicating that they were greatly influenced by the environment. Destro (1991) and Guerra (1995) in studies on soybean genotypes, including the 'edamame' soybean, obtained similar results.

Table 1. Means, general mean, variation coefficient (VC) and F value of nine traits for seven assessed treatments. UEL, Londrina, PR. Sowing on November 17,1996.

\begin{tabular}{cccccccccc}
\hline & \multicolumn{8}{c}{ Traits Assessed $^{1}$} \\
\cline { 2 - 9 } treatment $^{2}$ & $\mathrm{GP}^{3}$ & NDF & PHF & NDM & PHM & NSP & IPP & WHS & PMA \\
\hline 1 & $50.8 \mathrm{a}$ & $48.3 \mathrm{abc}$ & $26.2 \mathrm{ab}$ & $126.3 \mathrm{a}$ & $26.3 \mathrm{abc}$ & $22.4 \mathrm{~b}$ & $7.01 \mathrm{~b}$ & $31.1 \mathrm{a}$ & $887.5 \mathrm{abc}$ \\
2 & $45.3 \mathrm{a}$ & $47.8 \mathrm{~cd}$ & $26.3 \mathrm{ab}$ & $125.3 \mathrm{a}$ & $27.4 \mathrm{ab}$ & $26.3 \mathrm{~b}$ & $8.55 \mathrm{ab}$ & $31.9 \mathrm{a}$ & $991.7 \mathrm{ab}$ \\
3 & $26.0 \mathrm{bc}$ & $48.5 \mathrm{abc}$ & $21.9 \mathrm{~b}$ & $124.5 \mathrm{a}$ & $23.0 \mathrm{c}$ & $18.9 \mathrm{~b}$ & $5.90 \mathrm{~b}$ & $31.2 \mathrm{a}$ & $880.2 \mathrm{bc}$ \\
4 & $.30 .3 \mathrm{~b}$ & $48.8 \mathrm{ab}$ & $22.1 \mathrm{~b}$ & $125.0 \mathrm{a}$ & $23.7 \mathrm{bc}$ & $19.2 \mathrm{~b}$ & $6.13 \mathrm{~b}$ & $32.0 \mathrm{a}$ & $888.5 \mathrm{abc}$ \\
5 & $25.3 \mathrm{bc}$ & $49.0 \mathrm{a}$ & $24.0 \mathrm{~b}$ & $126.0 \mathrm{a}$ & $24.7 \mathrm{bc}$ & $21.7 \mathrm{~b}$ & $6.91 \mathrm{~b}$ & $31.8 \mathrm{a}$ & $778.2 \mathrm{c}$ \\
\hline 6 & $49.5 \mathrm{a}$ & $47.3 \mathrm{~d}$ & $28.1 \mathrm{a}$ & $124.5 \mathrm{a}$ & $28.7 \mathrm{a}$ & $36.1 \mathrm{a}$ & $11.8 \mathrm{a}$ & $33.1 \mathrm{a}$ & $996.9 \mathrm{a}$ \\
\hline General & $47.3 \mathrm{a}$ & $48.0 \mathrm{bcd}$ & $25.9 \mathrm{ab}$ & $126.3 \mathrm{a}$ & $25.9 \mathrm{abc}$ & $23.0 \mathrm{~b}$ & $7.20 \mathrm{~b}$ & $31.4 \mathrm{a}$ & $885.4 \mathrm{abc}$ \\
VC $(\%)$ & 39.2 & 48.2 & 25.1 & 125.4 & 25.7 & 23.6 & 7.51 & 31.4 & 86.9 \\
$\mathrm{~F}^{4}$ & 7.90 & 1.06 & 9.12 & 1.18 & 8.94 & 27.6 & 29.8 & 5.97 & 9.05 \\
\hline
\end{tabular}

${ }^{1}$ Means followed by different letters differ at the $5 \%$ level of probability by the Duncan test.

${ }^{2}$ Treat 1: Sowing in flower bed; Treat 2: Sowing in newspaper cups; Treat 3: Sowing in tubes V $=30 \mathrm{~cm}^{3}$; Treat 4 : Sowing tubes $\mathrm{V}=60 \mathrm{~cm}^{3}$; Treat 5: Sowing in tubes $\mathrm{V}=70 \mathrm{~cm}^{3}$; Treat 6: Sowing in disposable plastic cups; Treat 7: Sowing in styrofoam trays.

${ }^{3}$ GP: Germination percentage; NDF: Number of days to flowering; PHF: Plant height at flowering; NDM: Number of days to maturity; PHM: Plant height at maturity; NSP: Number of seeds per plant; IPP: Individual plant productivity; WHS: Weight per hundred seeds; PMA: Percentage of plants per plot at maturity.

$4 * *$ Significant at the level of $1 \%$ probability by the $\mathrm{F}$ test; * significant at the level of $5 \%$ probability by the $\mathrm{F}$ test; ns No significance by the F test.

The general mean for percentage of germination was $39.2 \%$. The low germination might be explained by the low physiological quality of the seeds of the Tamba Kurodaisu cultivar (Destro, 1994). The highest value obtained was $50.8 \%$ for the flower bed sowing treatment, which was statistically different from all the test tube treatments. The lowest values were $25.3 \%$, $26.0 \%$ and $30.3 \%$ for the volumes of $30 \mathrm{~cm}^{3}, 60$ $\mathrm{cm}^{3}$ and $70 \mathrm{~cm}^{3}$, respectively. The low germination was attributed to the diameter (2.6 $\mathrm{cm}$ ) of the containers of these treatments, which hindered emergence. It is recommended to carry out tests in tubes with larger diameters.
Regarding the trait number of plants per plot (NPP) seven days after transplanting, there was a difference in plants surviving in the treatments, varying from $91.7 \%$ for the test tube sowing $(\mathrm{V}=30 \mathrm{~cm} 3)$ to $100 \%$ for disposable plastic cups. There was a decrease in the number of plants in all the treatments after the seventh day (Figure 1). The sowing treatment in disposable plastic cups had the largest final stand, with $96.9 \%$ of the plants surviving while the three treatments with test tube sowing had the lowest values: $78.2 \%, 80.2 \%$ and $88.5 \%$ for the values $70 \mathrm{~cm}^{3}, 30 \mathrm{~cm}^{3}$ and $60 \mathrm{~cm}^{3}$, respectively. 
The general mean for days to flowering was 48.2 days. The maximum value obtained was 49 days for the test tube treatment $\left(\mathrm{V}=70 \mathrm{~cm}^{3}\right)$ which differed statistically by the Duncan test from the treatments sown in styrofoam trays, newspaper cups and disposable plastic cups, which had the lowest value (47.3 days). The mean number of days to maturity was 125.4 days. The highest value was 126.3 days for flower bed and styrofoam trays sowing, and the lowest was 124.5 days for test tubes $(\mathrm{V}=30$ $\mathrm{cm}^{3}$ ) and disposable plastic cups sowing. There were no statistically significant differences by the Duncan test, at the level of 5\% significance, for any of the treatments. The general mean for the plant height at flowering was $25.1 \mathrm{~cm}$. The maximum value obtained was $28.1 \mathrm{~cm}$ for sowing in disposable plastic cups. The minimum value obtained was $21.9 \mathrm{~cm}$ for sowing in test tubes treatment $\left(\mathrm{V}=30 \mathrm{~cm}^{3}\right)$. The general mean for plant height at maturity was $25.7 \mathrm{~cm}$; the highest value was obtained for sowings in disposable plastic cups $(28.7 \mathrm{~cm})$ which was statistically different by the Duncan test, from sowing in test tubes; the lowest value, $23.0 \mathrm{~cm}$, was found for sowing in test tubes (V $=30 \mathrm{~cm}^{3}$ ). The general mean for yield per individual plant was $7.51 \mathrm{~g} / \mathrm{plant}$. The maximum value was $11.8 \mathrm{~g} /$ plant for sowing in disposable plastic cups, which was significantly different from the other treatments by the Duncan test. Regarding the number of seeds per plant, the general treatment mean was 23.6 seeds. The highest value obtained was 36.1 seeds for sowing in disposable plastic cups, which was significantly different from the other treatments. The lowest value obtained was 18.9 seeds for sowing in tubes $\left(\mathrm{V}=30 \mathrm{~cm}^{3}\right)$. The mean weight of a hundred seeds for the seven treatments assessed was $31.4 \mathrm{~g}$. The maximum value was $33.1 \mathrm{~g} / 100$ seeds for sowing in disposable plastic cups, which was not different for the other treatments. The minimum value was 31.1 $\mathrm{g} / 100$ seeds for sowing in flower beds.

Sowing in disposable plastic cups had the best plant development until flowering and at maturity, and also had the highest yield per plant. Regarding the number of plants per plot, this treatment had the lowest death rate at all stages of development (Fig. I), and $96.9 \%$ of the plants could be harvested with maturity. These data showed a better adaptation of the root system to transplant when sowing in disposable plastic cups treatment was used. Furthermore, it was easy to obtain disposable plastic cups, which lowered the cost of setting up the crop.

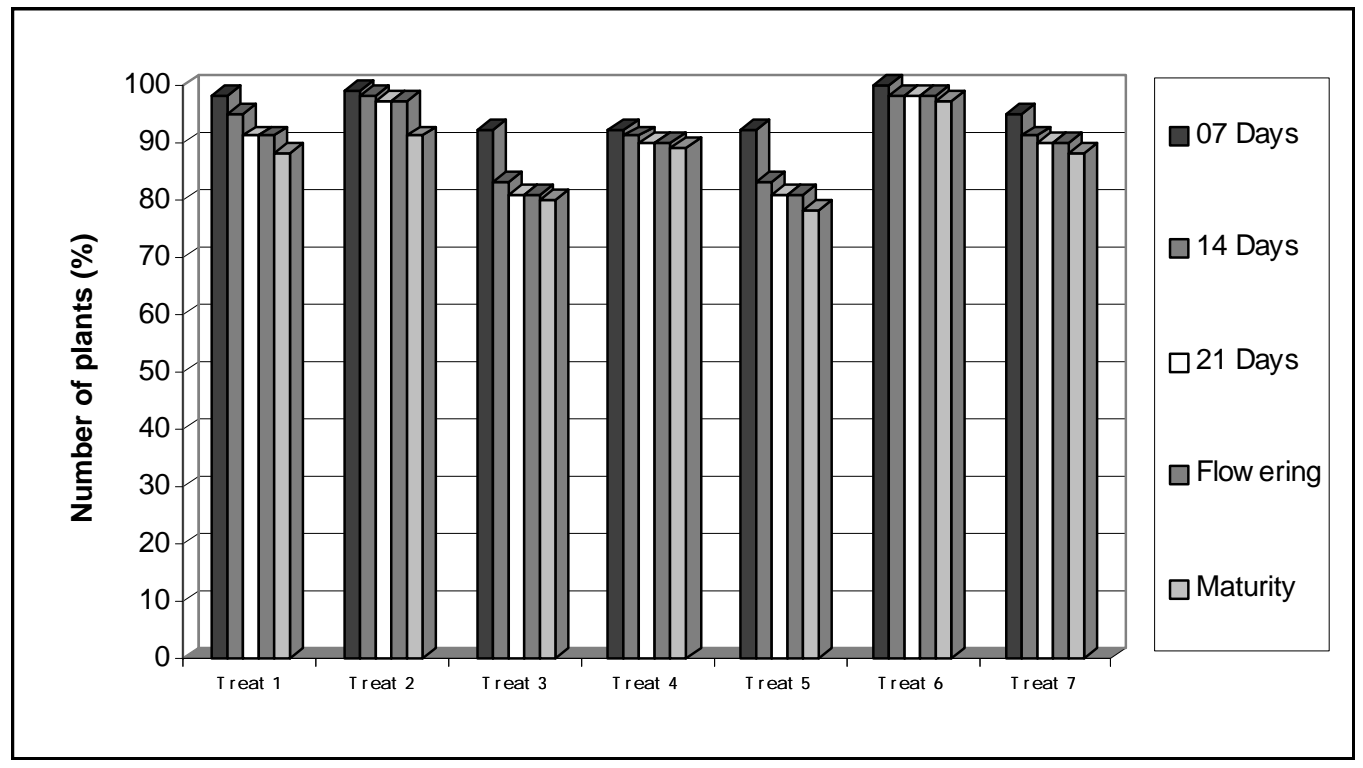

Fig 1. Survival percentage after transplant in different stages.

Treat 1: Sowing in flower bed; Treat 2: Sowing in newspaper cups; Treat 3: Sowing in tubes $\mathrm{V}=30 \mathrm{~cm}^{3}$; Treat 4: Sowing tubes $\mathrm{V}=60 \mathrm{~cm}^{3}$; Treat 5: Sowing in tubes $V=70 \mathrm{~cm}^{3}$; Treat 6: Sowing in disposable plastic cups; Treat 7: Sowing in styrofoam trays. 
The sowing in test tubes treatment had problems in germination, probably caused by the small diameter of the containers. The inferior plant development in these treatments may also be attributed to the small volume of substrate the containers hold. The data showed that there was less plant development and lower yield. A larger container may be used and would, probably, improve the development and yield of the plants. A suitable size test tubes for transplants of soybean with large seeds should be found. These containers are very durable and can be used for several seasons and thus the cost of acquiring the material can be reduced.

The sowing in flower bed treatment, most used by producers at the moment, was also a viable alternative. This treatment is very easy to use to set up large crop areas. In this case, part of the crop can be sown directly in the field, in rows spaced at $1.40 \mathrm{~m}$. One and two seeds are placed alternately in each hill spaced at $0.40 \mathrm{~m}$ in the row. The seeds are covered with sawdust to quicken emergence. Large areas over 10 hectares can be cropped. The producer can use more than one method to set up Tamba Kurodaisu soybean cultivar crops: sowing in disposable plastic cups or sowing in flower bed for later transplant and direct sowing in the field. The seeds should be treated with fungicides and inoculates before sowing.

\section{CONCLUSIONS}

1 - Sowing in disposable plastic cups with later transplant was better than the other treatments, and is recommended for Tamba Kurodaisu cultivar sowing.

2 - Where the use of disposable plastic cups is impractical, as in cropping of areas over 1 hectare, part of the sowing should be done in flower beds with later transplant and part as direct sowing in the field.

3 - Soybean crops can be set up with the Tamba Kurodaisu cultivar, using more than one method: sowing in disposable plastic cups or sowing in flower bed with later transplant and direct sowing in the field.

4 - The diameter of the containers and the substrate volume are related with the germination percentage and with the development of plants in the field.

\section{ACKNOWLEDGEMENT}

We are grateful to Conselho Nacional de Desenvolvimento Científico e Tecnológioco (CNPq) for financial support.

\section{RESUMO}

Atualmente, as lavouras com o cultivar Tamba Kurodaisu são semeadas em canteiros, para posterior transplante no campo. Este sistema tem causado falhas na lavoura, por ocorrer danificação no sistema radicular. Com o objetivo de testar diferentes alternativas de semeadura para obtenção de mudas visando a implantação de lavouras de soja tipo alimento, com sementes graúdas, instalou-se um experimento com os seguintes tratamentos: Semeadura em canteiros; Semeadura em copos de jornal, com volume (V) igual a $130 \mathrm{~cm}^{3}$; Semeadura em tubetes, com V $=30 \mathrm{~cm}^{3} ; \mathrm{V}=60$ $\mathrm{cm}^{3} ; \mathrm{V}=70 \mathrm{~cm}^{3}$; Semeadura em copos plásticos descartáveis, com V $=70 \mathrm{~cm}^{3}$; Semeadura em bandejas de isopor, com V $=90 \mathrm{~cm}^{3}$. O delineamento utilizado foi blocos casualizados, tendo sido avaliados os seguintes caracteres: Porcentagem de germinação; Número de plantas por parcela; Número de dias para o florescimento; Altura da planta no florescimento; Número de dias para a maturidade; Altura da planta na maturidade; Número de sementes por planta; Produtividade por planta individual; Peso de cem sementes. Para implantar as lavouras de soja com o cultivar Tamba Kurodaisu, pode se utilizar três maneiras: semeadura em copos plásticos descartáveis ou semeadura em canteiros com posterior transplantio e semeadura direta no campo. 


\section{REFERENCES}

Carrão-Panizzi, M. C. Valor nutritivo da soja e potencial de utilização na dieta brasileira. Londrina. Embrapa-CNPSo, 13p. 1988.

Destro, D. Capacidade de combinação de genótipos de soja apropriados para o consumo humano. Piracicaba. ESALQ, 1991. 157 p. Tese de Doutorado.

Destro, D.; Guerra, E. P. Vello, N. A. et al. Melhoramento genético da soja com sementes grandes. Revista Brasileira de Genética, Ribeirão Preto, v. 17, n. 3, Supl., p. 336, 1994.

Embrapa/Soja. Recomendações técnicas para a cultura da soja no Paraná 1996/97. Londrina. 1996. 187p. (Embrapa-CNPSo. Documentos, 97).

Fehr, W. R. ; Caviness, C. E. Stages of soybean development. Iowa. Iowa State Univ., 1977. 12p. Special Report 80.

Guerra, E. P. Seleção de parentais de soja tipo alimento por meio da divergência genética multivariada. Londrina. UEL, 1995. 85 p. Tese de Mestrado.

Hartwig, E. E. Varietal development. In: Caldwell, B. E. ed. Soybeans, improvement, production and uses. Madison, USA.
American Society of Agronomy, 1973. p.187-210. (Agronomy,16)

Konovsky, J.; Lumpkin, T.A. Edamame production and use: a global perspective. In: An International Conference Soybean Processing And Utilization. Julin Province, China. 1990. 12p.

Santos, A. L. C. Variabilidade entre genótipos de soja nas fases imaturas e maduras de desenvolvimento. Piracicaba. ESALQ, 1988. 135p. Tese de Mestrado.

Shanmugasundaram, S.; Li-Fen,C.; Maio-Rong, Y. Research on vegetable soybeans. In: An International Conference And Utilization. Jilin Province, China. 1990. 12p.

Vello, N. A. Ampliação da base genética do germoplasma e melhoramento da soja na ESALQ/USP. In: Câmara, G. M. S.; Marcos Filho, J.; Oliveira, E. A. M. (Eds). Simpósio sobre a Cultura e Produtividade da Soja. Piracicaba. Anais... Piracicaba. FEALQ, 1992. p-60-81.

Received: June 08, 1998;

Revised: June 22, 1998; Accepted: October 06, 1998. 